https://nv.nltu.edu.ua

https://doi.org/10.36930/40300104

$@ \bowtie$ Correspondence author

Article received 11.12.2019 p.

Article accepted 27.02.2020 p.

UDK 712.253:635.925(477.63-22)

O. E. Ivanchenko

ivanchenko_78@ukr.net

В. П. Бессонова, О. Є. Іванченко

Дніпровський держсавний аграрно-економічний університет, м. Дніпро, Україна

\title{
ВИДОВЕ БАГАТСТВО ДЕНДРОФЛОРИ ТА ЕСТЕТИЧНЕ ОЦНЮВАННЯ ФІТОЦЕНОЗІВ ПАРКУ СМТ МАГДАЛИНІВКА
}

Дендрофлора парку смт Магдалинівка налічує 347 прим., що належать до 19 видів і 15 родин. У насадженнях переважають Aesculus hippocastanum, Ulmus scabra, Betula pendula. Родини презентовані переважно 1-2 видами, за винятком Rosaceae. Родини Hippocastanaceae, Ulmaceae та Betulaceae мають найбільшу представленість за кількістю примірників, порівняно $з$ іншими. Частка видів аборигенної дендрофлори становить 53,32\%. Найбільша частка від загальної кількості інтродуцентів становлять представники з Південної та Південно-Східної Свропи. Переважна кількість дерев у насадженні має висоту від 8,1 до 10,0 м (23,3 \% щодо всіх рослин). За діаметром штамба переважають дерева зі значеннями цього показника від 22,1 до 26,0 см (16,1 \%), чисельними є групи рослин 3 діаметрами 26,1-30,0; 34,1-38,0 та від 18,1-22,0 см. Діаметр одного 3 найстаріших дерев парку Populus alba становить 108 см. За життєвим станом дещо більше половини насаджень належить до категорії "здорові", серед них багато примірників Betula pendula, Juglans regia, Ulmus scabra, Tilia cordata. До ослаблених належить 110 дерев, до сильно ослаблених - 43, до тих, що відмирають, - усього 6 шт. Індекс стану деревостану для парку становить 80,14, що характеризує його як здоровий. За екологічними вимогами асортимент парку тільки частково відповідає умовам зволоження території, проте майже повністю - родючості грунту. За таксаційно-фітоценотичною шкалою загальна естетичне оцінювання фітоценозу парку становить 31 бал. У парку ростуть дерева з вираженими фітонцидними властивостями, а саме: Acer platanoides, Betula pendula, Syringa vulgaris, а також Tilia cordata, Aesculus hippocastanum та Sorbus aucuparia.

Ключові слова: селищний парк; деревні насадження; видове різноманіття; таксаційні характеристики; життєвий стан; таксаційно-фітоценотична та емоційна шкали.

Вступ. У системі взаємопов'язаних озеленених просторів сади і парки - це мережа найбільших масивів насаджень, здатних із найкращим ефектом виконувати функції покращення мікрокліматичних умов [15] і організації масового відпочинку населення [22]. Останніми роками дослідники активно вивчають дендрофлору парків таких міст України, як: Чернігова [19], Вінниччини [25], Рівного [9] та ін., стан зелених насаджень у великих містах [17, 23], їхню ландшафтну організацію [12], пропонують проекти їх реконструкції ландшафтного середовища, враховуючи вже наявний сформований ландшафт і функціональне зонування [10]. Проте робіт із дослідження видового складу та життєвості деревних насаджень парків у селищах міського типу в Україні дуже мало. Основні відомості стосуються переважно парків, які належать до природно-заповідного фонду [21]. Парк у сучасному селищі $\epsilon$ важливим елементом озеленення, беручи на себе функції оздоровлення навколишнього середовища, збагачення сільського ландшафту, сприяння охороні природи й організації дозвілля населення.

Однією з головних причин реконструкції зелених насаджень у сформованих парках $є$ їх незадовільне планувальне і композиційне рішення, природне старіння деревно-чагарникових порід [7]. Асортимент деревних рослин більшості садово-паркових об'єктів підібрано без урахування абіотичних та антропогенних чинників, що склалися на їх території. В умовах міського середовища зелені насадження зазнають як техногенного, так і постійного рекреаційного навантаження, особливо у великих промислових містах [26]. Оскільки паркові насадження відіграють важливу роль у житті людини, для підтримання їх у належному стані потрібно виконувати моніторинг змін видового складу, періодичну інвентаризацію та оцінку їхнього життєвого стану з метою подальшої реконструкції та оптимізації. Тому дослідження біорізноманіття селищних паркових насаджень, оцінка їх життєвого стану та естетичності є сьогодні актуальним питанням, яке потребує опрацювання.

Об'єкт дослідження - дендрофлора паркових насаджень, життєвий стан насаджень та естетична привабливість парку.

Предмет дослідження - методи і засоби визначення видового багатства дендрофлори та естетичного оцінювання фітоценозів парку смт Магдалинівка

Мета дослідження - здійснити комплексне оцінювання видового різноманіття, життєвого стану та естетичної привабливості парку відпочинку смт Магдали-

\section{Інформація про авторів:}

Бессонова Валентина Петрівна, д-р біол. наук, професор, завідувач кафедри садово-паркового господарства. Email: spg.dsaeu@gmail.com; https://orcid.org/0000-0002-4310-0971

Іванченко Ольга Євгенівна, канд. біол. наук, доцент, кафедра садово-паркового господарства. Email: ivanchenko_78@ukr.net; https://orcid.org/0000-0002-4946-3116

Цитування за ДСтУ: Бессонова В. П., Іванченко О. Є. Видове багатство дендрофлори та естетичне оцінювання фітоценозів парку смт Магдалинівка. Науковий вісник НлтУ України. 2020, т. 30, № 1. С. 25-32.

Citation APA: Bessonova, V. P., \& Ivanchenko, O. E. (2020). Species richness of dendroflora and aesthetic assessment of phytocenoses of the park of Mahdalynivka town. Scientific Bulletin of UNFU, 30(1), 25-32. https://doi.org/10.36930/40300104 
нівка Дніпропетровської обл. Згідно з метою, основними завданнями дослідження було проаналізувати видовий склад деревних насаджень парку смт Магдалинівка, окремі таксаційні характеристики, фітосанітарний стан рослинних об'єктів, відповідність їх асортименту екологічним чинникам, а також виконати естетичну оцінку паркового фітоценозу за таксаційно-фітоценотичною та емоційною шкалами.

Наукова новизна дослідження полягає у тому, що вперше було досліджено видове біорізноманіття дендрофлори парку смт Магдалинівка, оцінено іiї фітосанітарний стан та деякі естетичні показники. Отримані результати будуть мати практичну значущість під час виконання робіт із благоустрою рекреаційного об'єкта та підбору асортименту деревних рослин.

Матеріали та методи дослідження. Магдалинівка це селище міського типу у Дніпропетровській обл., центр Магдалинівського р-ну. Магдалинівка розташована за 60 км на північ від міста Дніпро. Через селище протікає річка Чаплинка. Розміщене на березі річки Чаплинка, вище за течією на відстані 3,5 км розташоване село Водяне, нижче за течією примикає село Свдокієвка. На відстані 0,5 км розташоване село Оленівка. По селищу протікає кілька майже пересохлих струмків 3 загатами. Рельєф селища рівнинний, значних перепадів висот немає, оскільки воно розташоване в межах Придніпровської низовини.

Магдалинівський район належить до північно-східного агрокліматичного району $[14,20]$. Його кліматичні ресурси характеризуються такими показниками: кількість опадів за вегетаційний період - 350-380 мм, за рік близько 513 мм. Сума температур за період із температурою повітря вище $+10^{\circ} \mathrm{C}$ становить $3000-3050{ }^{\circ} \mathrm{C}$. Стійкий сніговий покрив відзначається не щороку. Відносна вологість повітря в середньому у теплий період року становить $74 \%$, найменша вона навесні- від $60 \%$, найбільша - восени (від 80\%). Кількість днів 3 відносною вологістю повітря більше ніж $30 \%$ та менше в літній період становить 35-45 днів, а на сході області - місцями 18-19 днів.
На території селища та району немає промислових підприємств, що забруднюють атмосферу. Магдалинівський район та смт Магдалинівка є одними з екологічно чистих місць проживання.

Парк відпочинку смт Магдалинівка розташований у центральній частині селища та має форму, що нагадує прямокутник. Площа парку відпочинку становить 17211 м $^{2}$. Його було закладено у 1970 р., періодично відновлювався, у ньому проводили реконструкції насаджень. Закладаючи парк відпочинку, були збережені деревні рослини, які знаходилися на території ще 3 1955 р. Декілька найстаріших дерев і дотепер продовжують рости серед молодших насаджень. Наймасштабніша реконструкція парку відбулась у 1980 р., коли було висаджено до 50 \% деревних і чагарникових рослин сьогоднішнього парку. У 1995 р. проводили часткову вибіркову реконструкцію парку.

Вміст рухомого фосфору у грунті парку смт Магдалинівка визначили методом Чирікова, обмінний калій за методом Кірсанова, азот - за Кравковим, гумус - за Тюріним $[2,8]$. Висоту дерев вимірювали висотоміром SUUNTOPM-5/1520, діаметр - мірною вилкою на висоті 1,3 м. Інформацію про вік насаджень вдалося отримати 3 архівних матеріалів Магдалинівського Історичного музею. Розподіл дерев у деревостані за класами життевості здійснювали за В. А. Алексєєвим. Розрахували індекси стану деревостану за кількістю дерев, які належать до різних класів життєвості [1].

Співвідношення екологічних груп рослин за відношенням до вологи та живильності грунту розрахували за шкалами $[3,18,27]$. Естетичну оцінку насаджень здійснювали за методикою [13].

Результати дослідження та їх обговорення. Дендрофлора парку смт Магдалинівка репрезентована 19 видами, які належать до 15 родин (табл. 2). Представленість видів рослин у родинах у насадженні парку не $є$ різноманітною. Тільки до родини Rosaceae належать три види - S. aucuparia, P. domestica, P. racemosa, але вони налічують всього по декілька примірників. До інших родин належать по 1-2 види (табл. 1).

Табл. 1. Таксономічний список дендрофлори парку смт Магдалинівка

\begin{tabular}{|c|c|c|c|c|c|}
\hline \multirow{2}{*}{$\begin{array}{l}\text { № } \\
\text { 3/ח }\end{array}$} & \multirow[b]{2}{*}{ Родина } & \multicolumn{2}{|c|}{ Вид, форма } & \multirow{2}{*}{$\begin{array}{c}\text { Кількість } \\
\text { примірників, } \\
\text { шт. }\end{array}$} & \multirow{2}{*}{$\begin{array}{c}\text { частка до за- } \\
\text { гальної кіль- } \\
\text { кості, \% }\end{array}$} \\
\hline & & латинська назва & ареал походження & & \\
\hline 1 & Соснові Pinaceae Lindl. & Picea pungens Engelm. & Північна Америка & 6 & 1,73 \\
\hline 2 & Кипарисові Cupressaceae Gray & Thuja occidentalis L. & Північна Америка & 4 & 1,15 \\
\hline 3 & Березові Betulaceae C. A. Agardh & Betula pendula Roth. & абориген & 49 & 14,12 \\
\hline 4 & Горіхові Juglandaceae Lindl. & Juglans regia $\mathrm{L}$. & Середня Азія & 32 & 9,22 \\
\hline \multirow{2}{*}{5} & \multirow{2}{*}{ В'язові Ulmaceae Mirb. } & Ulmus scabra Mill. & абориген & 58 & 16,71 \\
\hline & & Ulmus laevis Pall. & абориген & 8 & 2,31 \\
\hline \multirow{2}{*}{6} & \multirow{2}{*}{ Вербові Salicactae Lindl. } & Salix babylonica $\mathrm{L}$. & Китай, Іран & 8 & 2,31 \\
\hline & & Populus alba L. & абориген & 8 & 2,31 \\
\hline 7 & Липові Tiliaceae Mill. & Tilia cordata Mill. & абориген & 38 & 10,95 \\
\hline \multirow{3}{*}{8} & \multirow{3}{*}{ Розові Rosaceae Juss. } & Sorbus aucuparia L. & абориген & 8 & 2,31 \\
\hline & & Prunus domestica $\mathrm{L}$. & Закавказзя, Мала Азія, Іран & 3 & 0,86 \\
\hline & & Padus racemosa (Lam) Gilib. & абориген & 1 & 0,29 \\
\hline 9 & Бобові Fabaceae Lindl. & Robinia pseudoacacia $\mathrm{L}$. & Північна Америка & 8 & 2,31 \\
\hline 10 & Кленові Aceraceae Lindl. & Acer platanoides L. & абориген & 15 & 4,32 \\
\hline 11 & $\begin{array}{c}\text { Гіркокаштанові Hippocastanaceae } \\
\text { Torr, et Gray }\end{array}$ & Aesculus hippocastanum L. & $\begin{array}{c}\text { Гірські ліси Балканського } \\
\text { півострова, Македонія }\end{array}$ & 88 & 25,36 \\
\hline 12 & Симарубові Simaronbaceae Lindl. & Ailanthus altissima Swingl. & Північний Китай & 8 & 2,31 \\
\hline 13 & Гортензієві Hydrangeaceae Endl. & Philadelphus coronarius L. & Південна Європа & 1 & 0,29 \\
\hline 14 & Маслинові Oleaceae Lindl. & Syringa vulgaris $L$ & Балканський півострів & 2 & 0,57 \\
\hline 15 & Бігнонієві Bignoniaceae Juss & Catalpa bignonioides Walt. & Північна Америка & 2 & 0,57 \\
\hline \multicolumn{4}{|c|}{ Всього } & 347 & 100 \\
\hline
\end{tabular}


Панівне положення займає родина Hippocastanaceae - 25,36\%, родина Ulmaceae - 19,02\%, родина $B e$ tulaceae - 14,12\% від загальної кількості примірників деревних рослин у парку. Вони репрезентовані такими видами, як: A. hippocastanum, U. scabra та U. laevis, B. pendula. Невелику кількість примірників налічують родини Pinaceae, Cupressaceae, Oleaceae та Bignoniaceae. Їхня чисельність становить 1,$73 ; 1,15 ; 0,57$ та $0,57 \%$ відповідно від загальної чисельності дерев у насадженні (рис. 1).

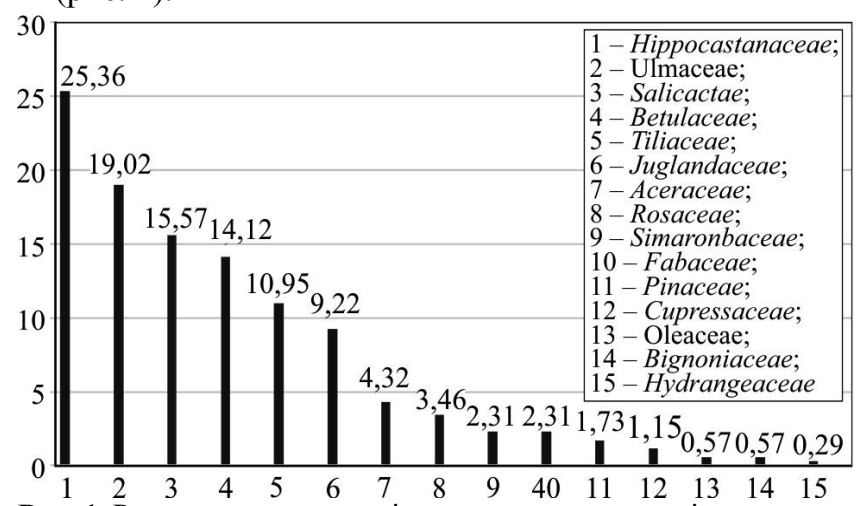

Рис. 1. Родинна представленість насаджень парку відпочинку смт Магдалинівка, \% від загальної кількості дерев: 1 - Нірроcastanaceae; 2 - Ulmaceae; 3 - Salicactae; 4 - Betulaceae; 5 - Tiliaceae; 6 - Juglandaceae; 7 - Aceraceae; 8 - Rosaceae; 9 - Simaronbaceae; 10 - Fabaceae; 11 - Pinaceae; 12 - Cupressaceae; 13 - Oleaceae; 14 - Bignoniaceae; 15 - Hydrangeaceae
Кількісна представленість видів дерев у парковому насадженні істотно відрізняється. Найчисельнішими є рослини таких видів, як: A. hippocastanum - 88 прим. $(23,36 \%)$, U. scabra - 58 прим. (16,71\%) та B. pendula 49 прим. (14,12 \%). Одиничними примірниками представлені Ph. coronarius та P. racemosa, двома примірниками - кожний $S$. vulgaris та $C$. bignonioides (див. табл. 1).

Деревні рослини парку смт Магдалинівка за декоративністю квіток можна поділити на дві групи: рослини, які мають високодекоративні квітки, та рослини, які їх не мають (див. табл. 2). До першої групи належать представники дев'яти видів рослин, загальна кількість яких становить 151 шт., до другої - десять видів. Їхня чисельність становить 196 шт. Отже, кількість гарноквітучих рослин менша, ніж рослин, що не мають високодекоративних квіток. У першій групі переважають $A$. hippocastanum та $T$. cordata, тоді як кількість таких гарноквітучих рослин, як: S. vulgaris, C. bignonioides, $P h$. coronarius, $P$. racemosa, дуже мала. Це свідчить про потреба збільшити їхню представленість у парку та доповнити асортимент іншими видами, такими як: Viburnum lantana L., Rosa rugosa Thunb., а також садовими трояндами (ремонтантні, гібридно-поліантові, флорибунда), ранньоквітучими видами Forsythia suspensa (Thunb.) Vahl. та F. intermedia Zab., Chaenomeles japoni$c a$ Lindl. Розміщення рослин здійснюється за систематичною, географічною, екологічною, декоративною або іншими ознаками.

Табл. 2. Розподіл деревних рослин за високодекоративними ознаками, \%

\begin{tabular}{|c|c|c|c|}
\hline $\begin{array}{c}\text { Гарноквітучі рослини, що мають } \\
\text { високодекоративні квітки }\end{array}$ & $\begin{array}{c}\text { Частка від загальної } \\
\text { кількості дерев, } \%\end{array}$ & $\begin{array}{c}\text { Рослини, що не мають } \\
\text { високодекоративних квіток }\end{array}$ & $\begin{array}{c}\text { Частка від загальної } \\
\text { кількості дерев, \% }\end{array}$ \\
\hline Aesculus hippocastanum & 25,36 & Ulmus scabra & 16,71 \\
\hline Tilia cordata & 10,95 & Ulmus laevis & 2,31 \\
\hline Sorbus aucuparia & 2,31 & Populus alba & 2,31 \\
\hline Robinia pseudoacacia & 2,31 & Betula pendula & 14,12 \\
\hline Prunus dometlica & 0,86 & Juglans regia & 9,22 \\
\hline Syringa vulgaris & 0,57 & Acer plantanoides & 4,32 \\
\hline Catalpa bignonioides & 0,57 & Salix babylonica & 2,31 \\
\hline Philadelphus coronarius & 0,29 & Ailanthus altissima & 2,31 \\
\hline Padus racemosa & 0,29 & Picea pungens & 1,73 \\
\hline Bсього & & Thuja occidentalis & 1,15 \\
\hline
\end{tabular}

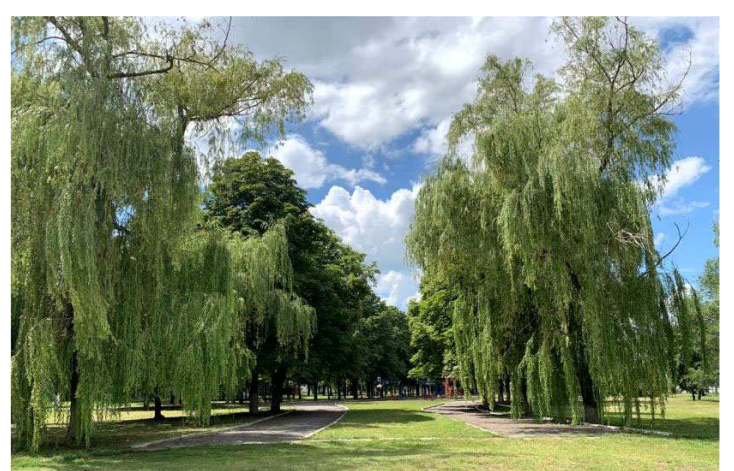

Рис. 2. Декоративні насадження S. babylonica у парку смт Магдалинівка

Досить декоративними є поодинокі симетричні насадження $S$. babylonica (рис. 2) та молоді насадження $T$. cordata (рис. 3). Нагадаємо, що декоративні рослини дерева, кущі й трав'янисті рослини, які вирощують для прикрашання міст, населених пунктів, внутрішнього озеленення приміщень з метою задоволення естетичних потреб людини. До декоративних належить численна група як культурних, так і дикорослих видів рослин.
Вони є серед представників трьох відділів: покритонасінних, голонасінних і папоротеподібних.

Видове різноманіття рослин у парку селища Магдалинівка недостатнє, порівняно з деякими іншими парками Дніпропетровської обл. [4, 5, 11]. Індекс видового багатства у цьому парку дорівнює 7,08 , тоді як у парках м. Дніпро, таких як: парки ім. Ю. Гагаріна, ім. Б. Хмельницького та Молодіжному, він становить 8,45; 10,84 та 11,97 відповідно, у парку культури і відпочинку м. Вільногірськ - 10,66. Варто відзначити дуже малу представленість хвойних рослин як кількісно, так і у видовому відношенні. До аборигенних видів належать $U$. scabra та U. laevis, $P$. alba, T. cordata, B. pendula, S. aucuparia, $A$. platanoides та $P$. racemosa. Їхня кількість - 53,32\%, чисельність інтродукованих видів - 46,68 \% від загальної кількості деревних рослин у парку.

Як видно 3 табл. 1, найбільша частка від загальної кількості інтродуцентів становлять представники з Південної та Південно-Східної Свропи - 91 прим. (гіркокаштан звичайний, бузок звичайний та садовий жасмин звичайний). Кількість рослин азіатської флори дорівнює 51 прим. і представлена чотирма видами. Північно- 
американська флора репрезентована також чотирма видами (20 прим.).

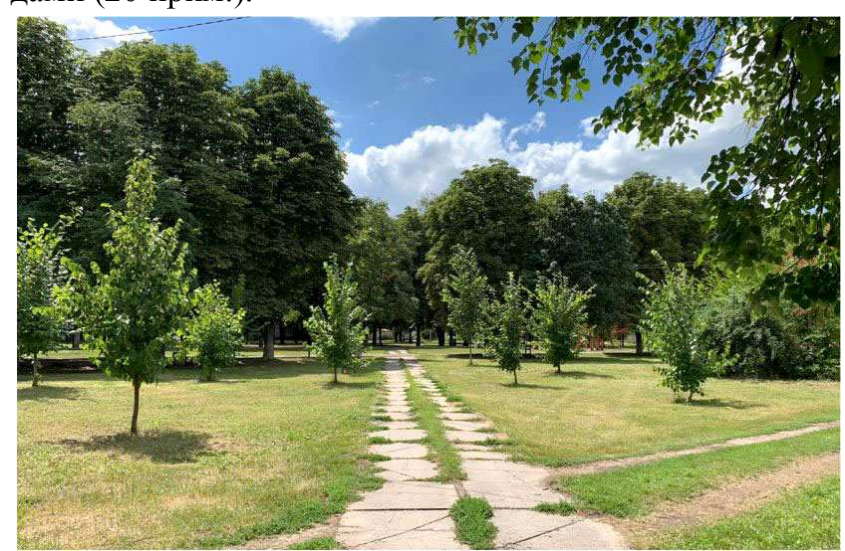

Рис. 3. Молоді насадження T. cordata у парку смт Магдалинівка
Найбільша кількість дерев у насадженні має висоту, що змінюється від 8,1 до 10,0 м. Це 23,3 \% від загальної чисельності дерев у парку, з них $32,9 \%-A$. hippocastanum, 22,4 \% - B. pendula, 30,0\% - T. cordata, 31,2 \%$J$. regia від усіх примірників цих видів (табл. 3). Дерева, які мають висоту в межах від 10,1 до 12,0 м, становлять 19,9 \% від загального обсягу дерев у насадженні, зокрема: $B$. pendula - 24,5\%, A. hippocastanum - 34,1\%, T. cordata - 29,0 \% (відносно чисельності рослин зазначених видів).

Кількість дерев 3 висотою від 12,1 до 14,0 м становить 15,0 \% від загальної їх кількості, з них найбільше представлені J. regia - 37,5\%, U. scabra - 17,2 \%, B. pendula - 20,4\% від кількості дерев у групі. Менше рослин належать до діапазону висот від 14,1 до 16,0 м9,8 \% від загальної кількості дерев, найбільш представлена B. pendula - 24,9 \% від кількості дерев у цій групі.

Табл. 3. Розподіл деревних рослин парку за висотами, м

\begin{tabular}{|c|c|c|c|c|c|c|c|c|c|c|c|c|c|}
\hline \multirow{2}{*}{ Назва рослини } & \multicolumn{12}{|c|}{ Висота, м } & \multirow{2}{*}{$\begin{array}{c}\text { Всього, } \\
\text { шт. }\end{array}$} \\
\hline & до 2,0 & $2,1-4,0$ & $4,1-6,0$ & $6,1-8,0$ & $8,1-10,0$ & $10,1-12,0$ & $\mid 12,1-14,0$ & $14,1-16,0$ & $16,1-18,0$ & $18,1-20,0$ & $20,1-22,0$ & $22,1-24,0$ & \\
\hline Acer platanoides & & & $2 / 13,3$ & $1 / 6,67$ & $2 / 13,3$ & $2 / 13,3$ & & & $3 / 20,0$ & $2 / 13,3$ & $2 / 13,3$ & $1 / 6,7$ & 15 \\
\hline Aesculus hippocastanum & & & $4 / 4,5$ & $8 / 9,1$ & $29 / 32,9$ & $30 / 34,1$ & $10 / 11,4$ & $6 / 6,8$ & $1 / 1,1$ & & & & 88 \\
\hline Ailanthus altissima & & $1 / 12,5$ & & & $2 / 25,0$ & $1 / 12,5$ & & & $2 / 25,0$ & $1 / 12,5$ & $1 / 12,5$ & & 8 \\
\hline Betula pendula & & & $2 / 4,1$ & $3 / 6,1$ & $11 / 22,4$ & $12 / 24,5$ & $10 / 20,4$ & $10 / 20,4$ & & $1 / 2,0$ & & & 49 \\
\hline Catalpa bignonioides & & & & & & $1 / 50,0$ & & & $1 / 50,0$ & & & & 2 \\
\hline Juglans regia & & & & & $10 / 31,2$ & $6 / 18,8$ & $12 / 37,5$ & $4 / 12,5$ & & & & & 32 \\
\hline Padus racemosa & & & $1 / 100,0$ & & & & & & & & & & 1 \\
\hline Populus alba & & & & $1 / 12,5$ & $2 / 25,0$ & $1 / 12,5$ & $1 / 12,5$ & $1 / 12,5$ & & $1 / 12,5$ & & $1 / 12,5$ & 8 \\
\hline Philadelphus coronarius & $1 / 100,0$ & & & & & & & & & & & & 1 \\
\hline Picea pungens & & & $1 / 16,7$ & & $3 / 50,0$ & $2 / 33,3$ & & & & & & & 6 \\
\hline Prunus domeslica & & & $1 / 33,3$ & $2 / 66,7$ & & & & & & & & & 3 \\
\hline Robinia seudoacacia & $1 / 12,5$ & $1 / 12,5$ & $1 / 12,5$ & $1 / 12,5$ & & & $2 / 25,0$ & $1 / 12,5$ & & & $1 / 12,5$ & & 8 \\
\hline Salix babylonica & & & & & $1 / 12,5$ & & $4 / 50,0$ & $3 / 37,5$ & & & & & 8 \\
\hline Sorbus aucuparia & & & $5 / 62,5$ & & $3 / 37,5$ & & & & & & & & 8 \\
\hline Syringa vulgaris & & $2 / 100,0$ & & & & & & & & & & & 2 \\
\hline Thuja occidentalis & & & $4 / 100,0$ & & & & & & & & & & 4 \\
\hline Tilia cordata & & & $4 / 10,5$ & $10 / 26,3$ & $10 / 30,0$ & $11 / 29,0$ & $1 / 2,6$ & $1 / 2,6$ & & $1 / 2,6$ & & & 38 \\
\hline Ulmus laevis & & & & $2 / 25,0$ & $2 / 25,0$ & $1 / 12,5$ & $2 / 25,0$ & $1 / 12,5$ & & & & & 8 \\
\hline Ulmus scabra & & $1 / 1,7$ & $4 / 6,9$ & $4 / 6,9$ & $6 / 10,3$ & $2 / 3,4$ & $10 / 17,2$ & $7 / 12,1$ & $12 / 20,7$ & $8 / 13,8$ & $3 / 5,2$ & $1 / 1,7$ & 58 \\
\hline $\begin{array}{l}\text { Частка від загальної } \\
\text { кількості дерев, \% }\end{array}$ & $2 / 0,6$ & $5 / 1,4$ & $29 / 8,4$ & $32 / 9,2$ & $81 / 23,3$ & $69 / 19,9$ & $52 / 15,0$ & $34 / 9,8$ & $19 / 5,5$ & $14 / 4,0$ & $7 / 2,0$ & $3 / 0,9$ & $\frac{347}{100}$ \\
\hline
\end{tabular}

Майже така ж $є$ чисельність примірників заввишки від 6,1 до 8,0 м - 9,2 \% від загальної кількості дерев у насадженні. Найбільш представлені T. cordata - 31,3 \% та A. hippocastanum - 25,0 \% від кількості дерев у групі. Найменша кількість дерев має висоту до 2 м, всього 0,6 \%. Це R. pseudoacacia (1 прим., результат самосіву) та поодинокий примірник Ph. coronarius. Найвищих дерев (22,1-24,0 м) у насадженнях - всього 3 прим. (0,9\% щодо всіх рослин парку). Це по одній особині $A$. platanoides, $P$. alba та U. scabra.

Перший ярус у парковому фітоценозі складають $U$. scabra, A. plantanoides, R. pseudoacacia, P. alba, A. altissima. До другого ярусу належать $A$. hippocastanum, T. cordata, J. regia, U. laevis, B. pendula, C. bignonioides, $S$. babylonica, $P$. pungens, $P$. domestica. У третьому ярусі $\in P$. racemosa, T. occidentalis, $P$ h. coronarius, $S$. vulgaris, $S$. aucuparia. Як видно з табл. 4, у насадженнях переважають дерева 3 діаметром від 22,1 до 26,0 см - 53 шт. (16,1 \% від загальної кількості дерев у насадженні). У цій групі найчисленніші види - A. hippocastanum, $B$. pendula та $T$. cordata $(20,5 ; 26,5$ та $26,3 \%$ від кількості представників виду відповідно).

Рослин із діаметрами від 26,1 до $30 \mathrm{~cm}-38$ шт., це становить 11,5 \% від загальної кількості деревних рос- лин у насадженні. Серед них переважають $B$. pendula (14,3\% від чисельності представників виду відповідно), T. cordata (26,3\%), A. hippocastanum (12,5\% відповідно). Також чисельні групи дерев із діаметрами від 34,1 до 38 см та від 18,1 до 22 м, найбільш представлені у першій групі $€$ A. hippocastanum та $B$. pendula. Найменшу кількість рослин віднесено до групи 3 діаметрами від 70,1 до $74 \mathrm{~cm}-0,3 \%$, від 58,1 до $62 \mathrm{~cm}$ та від 78,1 до $82 \mathrm{~cm}-0,6 \%$.

Група дерев із діаметрами від 66,1 до 70 см у парку становить 0,9\%. Це U. scabra та S. babylonica. Представники деревних насаджень 3 діаметрами більше ніж 82,1 см також становлять 0,9 \% від загальної кількості дерев, серед них $P$. alba, U. laevis та U. scabra $(1,71$; 12,5 та $12,5 \%$ та від усієї кількості представників цих видів відповідно). Товщина стовбура $P$. alba, одного 3 найстаріших дерев Магдалинівського парку відпочинку, становить 108 см, а висота дерева - 17 м.

Такі види рослин, як: P. pungens, T. occidentalis, $P$. domestia, P. domestica, C. bignonioides, P. racemosa, не включені до табл. 5, оскільки через малу чисельність вони входять тільки до однієї або двох груп. Так, п'ять дерев P.pungens віднесено до класу діаметрів 18,122,0 і 26,1-30,0 см, 4 дерева T. occidentalis - 6,1-10,0 м. 
Дві рослини $P$. domestia входять у групу 10,1-14 см і одна - 14,1-18 см, до цієї ж групи віднесено й одну рослину $P$. racemosa. Одне дерево $C$. bignonioides має діаметр 24,2 см і одне - 32,6 см. Отже, найбільша кількість дерев має величину діаметра в діапазоні 22,1-26,0 м, дещо менша їхня чисельність з цим показником у групах 34,1-38,0 і 26,1-30,0 см.

Розподіл дерев за життєвим станом свідчить про те, що найбільша їх кількість належить до 1 класу (здорові) - 183 прим. (див. табл. 5). 3 них найчисельніші
B. pendula - 48 шт., що становить 97,96 \% від загальної чисельності виду; J. regia - 28 шт. (87,5\%); U. scabra25 шт. (44,07\%), T. cordata - 25 шт. (65,79\%). До 2-го класу (ослаблені) належить 110 дерев, $з$ яких 17 прим. U. scabra та 60 прим. - A. hippocastanum. Найбільшою кількістю примірників у 3-й категорії (сильно ослаблені дерева) представлені A. hippocastanum та U. scabra23 і 13 прим., що становить 22,04 та 26,13\% від кількості особин цих видів відповідно.

Табл. 4. Розподіл деревних рослин парку за діаметром, см

\begin{tabular}{|c|c|c|c|c|c|c|c|c|c|c|c|c|c|c|c|c|c|c|c|c|c|c|}
\hline Назва & 1 П० 6 & 6,1- & $10,1-$ & $14,1-$ & $18,1-$ & $22,1-$ & $26,1-$ & $30,1-$ & $34,1-$ & $38,1-$ & $42,1-$ & $46,1-$ & $50,1-$ & $54,1-$ & $58,1-$ & $62,1-$ & $66,1-$ & $70,1-$ & $74,1-$ & $78,1-$ & $>$ & Всьо- \\
\hline рослини & 2006 & 10,0 & 14 & 18 & 22 & 26 & 30 & 34 & 38 & 42 & 46 & 50 & 54 & 58 & 62 & 66 & 70 & 74 & 78 & 82 & 82,1 & Го \\
\hline $\begin{array}{c}\text { Acer } \\
\text { platanoides }\end{array}$ & & & & $\begin{array}{c}2 \\
13,3\end{array}$ & $\begin{array}{c}1 \\
6,7\end{array}$ & $\begin{array}{c}2 \\
13,3\end{array}$ & $\begin{array}{c}3 \\
20,0\end{array}$ & $\begin{array}{c}3 \\
20,0\end{array}$ & & $\begin{array}{c}2 \\
13,3\end{array}$ & & $\begin{array}{c}1 \\
6,7\end{array}$ & $\begin{array}{c}1 \\
6,7\end{array}$ & & & & & & & & & 15 \\
\hline $\begin{array}{l}\text { Aesculus hip- } \\
\text { pocastanum }\end{array}$ & & $\begin{array}{c}1 \\
1,1\end{array}$ & $\begin{array}{c}1 \\
1,1\end{array}$ & $\begin{array}{c}3 \\
3,5\end{array}$ & $\begin{array}{c}7 \\
7,9\end{array}$ & $\begin{array}{c}18 \\
20,5\end{array}$ & $\begin{array}{c}11 \\
12,5\end{array}$ & $\begin{array}{c}11 \\
12,5\end{array}$ & $\begin{array}{c}17 \\
19,4\end{array}$ & $\begin{array}{c}10 \\
11,4\end{array}$ & $\begin{array}{c}4 \\
4,5\end{array}$ & $\begin{array}{c}1 \\
1,1\end{array}$ & $\begin{array}{c}3 \\
3,4\end{array}$ & $\begin{array}{c}1 \\
1,1\end{array}$ & & & & & & & & 88 \\
\hline $\begin{array}{c}\text { Ailanthus } \\
\text { altissima }\end{array}$ & \begin{tabular}{|c|}
1 \\
12,5 \\
\end{tabular} & & & $\begin{array}{c}1 \\
12,5 \\
\end{array}$ & & $\begin{array}{c}1 \\
12,5 \\
\end{array}$ & & $\begin{array}{c}1 \\
12,5 \\
\end{array}$ & & & $\begin{array}{c}1 \\
12,5 \\
\end{array}$ & \begin{tabular}{|c|}
1 \\
12,5 \\
\end{tabular} & \begin{tabular}{|c|}
1 \\
12,5 \\
\end{tabular} & $\begin{array}{c}1 \\
12,5 \\
\end{array}$ & & & & & & & & 8 \\
\hline $\begin{array}{c}\text { Betula } \\
\text { pendula }\end{array}$ & & & & $\begin{array}{c}13 \\
26,5 \\
\end{array}$ & $\begin{array}{c}10 \\
20,4\end{array}$ & $\begin{array}{c}13 \\
26,5\end{array}$ & $\begin{array}{c}7 \\
14,3 \\
\end{array}$ & $\begin{array}{c}2 \\
4,1\end{array}$ & $\begin{array}{c}2 \\
4,1\end{array}$ & $\begin{array}{c}1 \\
2,0\end{array}$ & $\begin{array}{c}1 \\
2,0\end{array}$ & & & & & & & & & & & 49 \\
\hline Juglans regia & $\begin{array}{c}2 \\
6,3\end{array}$ & $\begin{array}{c}2 \\
6,3\end{array}$ & $\begin{array}{c}1 \\
3,1\end{array}$ & $\begin{array}{c}2 \\
6,3\end{array}$ & $\begin{array}{c}3 \\
9,3\end{array}$ & $\begin{array}{c}1 \\
3,1\end{array}$ & $\begin{array}{c}3 \\
9,3\end{array}$ & $\begin{array}{c}5 \\
15,6\end{array}$ & $\begin{array}{c}5 \\
15,6\end{array}$ & $\begin{array}{c}5 \\
15,6\end{array}$ & $\begin{array}{c}1 \\
3,1\end{array}$ & $\begin{array}{c}1 \\
3,1\end{array}$ & $\begin{array}{c}1 \\
3,1\end{array}$ & & & & & & & & & 32 \\
\hline Populus alba & & & & $\begin{array}{c}2 \\
25\end{array}$ & $\begin{array}{c}1 \\
12,5\end{array}$ & & & & & $\begin{array}{c}1 \\
12,5\end{array}$ & \begin{tabular}{c|}
1 \\
12,5
\end{tabular} & & & & & & & $\begin{array}{c}1 \\
12,5\end{array}$ & & $\begin{array}{c}1 \\
12,5\end{array}$ & $\begin{array}{c}1 \\
12,5\end{array}$ & 8 \\
\hline $\begin{array}{c}\text { Robinia } \\
\text { seudoacacia }\end{array}$ & \begin{tabular}{|c|}
1 \\
12,5 \\
\end{tabular} & & & & $\begin{array}{c}1 \\
12,5 \\
\end{array}$ & & $\begin{array}{c}1 \\
12,5 \\
\end{array}$ & $\begin{array}{c}2 \\
25 \\
\end{array}$ & & $\begin{array}{c}1 \\
12,5 \\
\end{array}$ & \begin{tabular}{|c|}
1 \\
12,5 \\
\end{tabular} & \begin{tabular}{|c|}
1 \\
12,5 \\
\end{tabular} & & & & & & & & & & 8 \\
\hline $\begin{array}{c}\text { Salix } \\
\text { babylonica }\end{array}$ & & & & & & & & & & $\begin{array}{c}1 \\
12,5 \\
\end{array}$ & & \begin{tabular}{|c|}
3 \\
37,5 \\
\end{tabular} & & & $\begin{array}{c}1 \\
12,5 \\
\end{array}$ & $\begin{array}{c}1 \\
12,5 \\
\end{array}$ & $\begin{array}{c}1 \\
12,5\end{array}$ & & & $\begin{array}{c}1 \\
12,5\end{array}$ & & 8 \\
\hline $\begin{array}{c}\text { Sorbus } \\
\text { aucuparia }\end{array}$ & & & $\begin{array}{c}1 \\
12,5 \\
\end{array}$ & $\begin{array}{c}2 \\
25,0 \\
\end{array}$ & $\begin{array}{c}3 \\
37,5 \\
\end{array}$ & $\begin{array}{c}1 \\
12,5 \\
\end{array}$ & & $\begin{array}{c}1 \\
12,5 \\
\end{array}$ & & & & & & & & & & & & & & 8 \\
\hline Tilia cordata & & $\begin{array}{c}1 \\
2,6\end{array}$ & $\begin{array}{c}1 \\
2,6\end{array}$ & $\begin{array}{c}3 \\
7,9\end{array}$ & \begin{tabular}{|c|}
5 \\
13,2
\end{tabular} & $\begin{array}{c}10 \\
26,3\end{array}$ & $\begin{array}{c}10 \\
26,3\end{array}$ & \begin{tabular}{|c|}
4 \\
10,5 \\
\end{tabular} & $\begin{array}{c}3 \\
7,9\end{array}$ & $\begin{array}{c}1 \\
2,6\end{array}$ & & & & & & & & & & & & 38 \\
\hline Ulmus laevis & & & & $\begin{array}{c}2 \\
25\end{array}$ & $\begin{array}{c}1 \\
12,5\end{array}$ & $\begin{array}{c}2 \\
25\end{array}$ & & & & & & & & $\begin{array}{c}2 \\
25\end{array}$ & & & & & & & \begin{tabular}{|c|}
1 \\
12,5 \\
\end{tabular} & 8 \\
\hline $\begin{array}{c}\text { Ulmus } \\
\text { scabra }\end{array}$ & $\begin{array}{c}1 \\
1,7\end{array}$ & & & & $\begin{array}{c}1 \\
1,7\end{array}$ & $\begin{array}{c}5 \\
8,5\end{array}$ & $\begin{array}{c}3 \\
5,1\end{array}$ & $\begin{array}{c}2 \\
3,4\end{array}$ & $\begin{array}{c}7 \\
11,8 \\
\end{array}$ & \begin{tabular}{c|}
8 \\
13,6 \\
\end{tabular} & \begin{tabular}{|c|}
9 \\
15,3 \\
\end{tabular} & $\begin{array}{c}7 \\
11,8 \\
\end{array}$ & $\begin{array}{c}5 \\
8,5 \\
\end{array}$ & $\begin{array}{c}4 \\
6,8 \\
\end{array}$ & $\begin{array}{c}1 \\
1,7 \\
\end{array}$ & $\begin{array}{c}3 \\
5,1\end{array}$ & $\begin{array}{c}2 \\
3,4 \\
\end{array}$ & & & & \begin{tabular}{c|}
1 \\
1,7 \\
\end{tabular} & 59 \\
\hline Всього & $\begin{array}{c}5 \\
1,5\end{array}$ & $\begin{array}{c}4 \\
1,2\end{array}$ & $\begin{array}{c}4 \\
1,2\end{array}$ & $\begin{array}{l}30 \\
9,1\end{array}$ & $\begin{array}{c}33 \\
10,0\end{array}$ & $\begin{array}{c}53 \\
16,1\end{array}$ & \begin{tabular}{|c|}
38 \\
11,5
\end{tabular} & $\begin{array}{l}31 \\
9,4\end{array}$ & $\begin{array}{c}34 \\
10,3\end{array}$ & $\begin{array}{l}30 \\
9,1\end{array}$ & $\begin{array}{l}18 \\
5,5\end{array}$ & $\begin{array}{c}15 \\
4,6\end{array}$ & $\begin{array}{c}11 \\
3,3\end{array}$ & $\begin{array}{c}8 \\
2,4\end{array}$ & $\begin{array}{c}2 \\
0,6\end{array}$ & $\begin{array}{c}4 \\
1,2\end{array}$ & $\begin{array}{c}3 \\
0,9\end{array}$ & $\begin{array}{c}1 \\
0,3\end{array}$ & $\begin{array}{l}0 \\
0\end{array}$ & $\begin{array}{c}2 \\
0,6\end{array}$ & $\begin{array}{c}3 \\
0,9\end{array}$ & $\begin{array}{l}329 \\
100 \\
\end{array}$ \\
\hline
\end{tabular}

Примітка: у чисельнику - кількість рослин, що належать до цього класу діаметра; у знаменнику - частка щодо кількості особин цього виду; у таблиці наведено тільки деревні життєві форми.

Табл. 5. Розподіл дерев у деревостані парку відпочинку за класами життєвості В. А. Алєксєєва [1]

\begin{tabular}{|c|c|c|c|c|c|c|c|c|c|c|}
\hline \multirow{3}{*}{ Вид } & \multicolumn{10}{|c|}{ Кількість (шт.) та \% від загальної кількості виду } \\
\hline & \multicolumn{2}{|c|}{ 1-й клас } & \multicolumn{2}{|c|}{ 2-й клас } & \multicolumn{2}{|c|}{ 3-й клас } & \multicolumn{2}{|c|}{ 4-й клас } & \multicolumn{2}{|c|}{ 5-й клас } \\
\hline & шт. & $\%$ & шт. & $\%$ & ШТ. & $\%$ & ШТ. & $\%$ & ШТ. & $\%$ \\
\hline Acer platanoides & 12 & 80,0 & 3 & 20,0 & - & & - & & - & \\
\hline Aesculus hippocastanum & 2 & 2,27 & 60 & 68,18 & 23 & 26,13 & 2 & 2,27 & 1 & 1,14 \\
\hline Ailanthus altissima & 8 & 100,0 & - & & - & & & & - & \\
\hline Betula pendula & 48 & 97,96 & - & & - & & - & & 1 & 2,04 \\
\hline Catalpa bignonioides & 2 & 100,0 & & & & & & & & \\
\hline Juglans regia & 28 & 87,5 & 4 & 12,5 & - & & - & & - & \\
\hline Philadelphus coronarius & - & & 1 & 100,0 & - & & - & & - & \\
\hline Padus racemosa & 1 & 100,0 & - & & - & & - & & - & \\
\hline Picea pungens & 2 & 33,32 & 4 & 66,67 & - & & - & & - & \\
\hline Populus alba & 3 & 37,5 & 4 & 50,0 & 1 & 12,5 & - & & - & \\
\hline Prunus domeslica & 2 & 66,67 & 1 & 33,32 & - & & - & & - & \\
\hline Robinia pseudoacacia & 2 & 25,0 & 6 & 75,0 & - & & - & & - & \\
\hline Salix babylonica & 8 & 100,0 & - & & - & & - & & - & \\
\hline Sorbus aucuparia & 7 & 87,5 & - & & - & & 1 & 12,5 & - & \\
\hline Syringa vulgaris & - & & 2 & 100,0 & - & & - & & - & \\
\hline Thuja occidentalis & - & & - & & 4 & 100,0 & - & & - & \\
\hline Tilia cordata & 25 & 65,79 & 8 & 21,05 & 2 & 5,26 & 1 & 2,64 & 2 & 5,26 \\
\hline Ulmus scabra & 25 & 44,07 & 17 & 28,81 & 13 & 22,04 & 2 & 3,39 & 1 & 1,69 \\
\hline Ulmus laevis & 8 & 100,0 & - & & - & & - & & - & \\
\hline \multirow{2}{*}{$\begin{array}{c}\text { Всього, \% від загальної } \\
\text { кількості дерев }\end{array}$} & 183 & & 110 & & 43 & & 6 & & 5 & \\
\hline & \multicolumn{2}{|c|}{$52,73 \%$} & \multicolumn{2}{|c|}{$31,70 \%$} & \multicolumn{2}{|c|}{$12,39 \%$} & \multicolumn{2}{|c|}{$1,73 \%$} & \multicolumn{2}{|c|}{$1,44 \%$} \\
\hline
\end{tabular}


До 4-го класу (дерева, що відмирають) віднесено 6 особин, із них A. hippocastanum та U. scabra - по два примірники, і по одній рослині таких видів, як: T. cordata та $S$. aucuparia. До 5-го класу (сухостій) належить 5 дерев, по одному примірнику $A$. hippocastanum, U.scabra, B. pendula та 2 примірники T. cordata (див. табл. 5). Алексєєв В. А. [1] запропонував формулу для розрахунків індексу стану деревостану за числом дерев, які належать до різних класів життєвості. Цей індекс для парку відпочинку смт Магдалинівка становить 80,14, що свідчить про те, що насадження загалом здорове, хоча ця цифра і знаходиться на межі нижнього показника оцінки "здоровий".

У насадженні виявлено випадки фаутності дерев, такі як: викривлення стовбура (T. cordata - 3 прим., $P$. pungens - 1 прим., береза повисла - 1 прим.), відхилення від вертикальної осі (B. pendula - 2 прим.), капи - у 14 дерев U. scabra, що становить 20,3\% від загальної кількості рослин цього виду. Трапляються морозобійні тріщини (A. hippocastanum - 1 прим., T. cordata3 прим.), всихання гілок (U. laevis, B. pendula, P. pungens). Дупла виявлено у двох рослин U. scabra й однієї рослини $B$. pendula. Механічно пошкоджене лише одне дерево парку - U. scabra.

Табл. 6. Розподіл деревних рослин парку відпочинку за відношенням до вологи

\begin{tabular}{|c|c|c|c|}
\hline Група & Вид & $\begin{array}{c}\text { Кі-сть, } \\
\text { шт. }\end{array}$ & \begin{tabular}{|c|} 
Частка від \\
заг. кількості \\
дерев, \%
\end{tabular} \\
\hline \multirow{3}{*}{ Ксерофіти } & Robinia pseudoacacia & 8 & 2,30 \\
\hline & \multirow{2}{*}{ Ailanthus altissima } & \multirow[t]{2}{*}{8} & 2,30 \\
\hline & & & всього 4,61 \\
\hline $\begin{array}{l}\text { Мезоксеро- } \\
\text { фіти }\end{array}$ & Juglans regia & 32 & 9,22 \\
\hline \multirow{6}{*}{$\begin{array}{c}\text { Ксеромезо- } \\
\text { фіти }\end{array}$} & Philadelphus coronarius & 1 & 0,29 \\
\hline & Syringa vulgaris & 2 & 0,57 \\
\hline & Picea pungens & 6 & 1,73 \\
\hline & Thuja occidentalis & 4 & 1,15 \\
\hline & \multirow[t]{2}{*}{ Catalpa bignonioides } & \multirow[t]{2}{*}{2} & 0,57 \\
\hline & & & всього 1,43 \\
\hline \multirow{6}{*}{ Мезофіти } & Acer plantanoides & 15 & 4,32 \\
\hline & Aesculus hippocastanum & 88 & 25,36 \\
\hline & Tilia cordata & 38 & 10,95 \\
\hline & Prunus domestica & 3 & 0,86 \\
\hline & \multirow[t]{2}{*}{ Betula pendula } & \multirow[t]{2}{*}{49} & 14,12 \\
\hline & & & всього 55,62 \\
\hline \multirow{7}{*}{$\begin{array}{c}\text { Мезогігрофі- } \\
\text { ти }\end{array}$} & Populus alba & 8 & 2,30 \\
\hline & Ulmus laevis & 8 & 2,30 \\
\hline & Sorbus aucuparia & 8 & 2,30 \\
\hline & Ulmus scabra & 58 & 16,71 \\
\hline & Salix babylonica & 8 & 2,30 \\
\hline & \multirow[t]{2}{*}{ Padus racemosa } & \multirow[t]{2}{*}{1} & 0,29 \\
\hline & & & всього 26,20 \\
\hline
\end{tabular}

Табл. 8. Таксаційно-фітоценотична шкала естетичного оцінювання фітоценозу парку відпочинку смт Магдалинівка [13]

\begin{tabular}{|l|c|c|}
\hline \multicolumn{1}{|c|}{ Таксаційно-фітоценотичні ознаки } & Група в межах ознаки & Кількість балів \\
\hline \multicolumn{1}{|c|}{} & І & 3 \\
\hline Бонітет клас & 3 \\
\hline Вологість грунту & сухі & 2 \\
\hline Характер рельєфу & рівний & 2 \\
\hline Ярусність головної синузії & триярусна & 3 \\
\hline Підріст & незадовільний & 1 \\
\hline Підлісок & рідкий & 1 \\
\hline Трав'яний покрив & бідний & 3 \\
\hline Густота трав'яного покриву & середньої густоти (75-80 \%) & 2 \\
\hline Вік деревостану & середньовікове насадження & 2 \\
\hline Повнота деревостану & 0,6 & 3 \\
\hline
\end{tabular}
показав, що 55,62 \% насадження парку - це мезофіти, головними представниками яких є A. hippocastanum, $B$. pendula, T. cordata, A. platanoides, P. domeslica) (табл. 6). Частка мезогігрофітів становить 26,20\%, найчисельнішим у ній є U. scabra.

Оскільки парк розташований у незрошуваних умовах, а залягання грунтових вод сягає близько 4 м, можна стверджувати, що групи деревних рослин, які належать до ксерофітів та ксеромезофітів, нормально розвиваються і не перебувають у пригніченому стані, оскільки вони стійкі до посухи. Але їхня кількість становить всього 8,92 \%. Ксерофіти репрезентовані всього двома видами - R. pseudoacacia і A. altissima, ксеромезофіти п’ятьма видами. Тому звичайно, що насадження з переважанням мезофітів та мезогігрофітів у період літньої спеки перебувають у пригніченому стані. Цей висновок можна зробити, враховуючи дані про кліматичні умови досліджуваного парку: рівень забезпечення вологою асортименту дерев та чагарників парку нижчий від середнього, а посушливі періоди тривають до 30 діб. Останніми роками спостерігають тенденцію до збільшення тривалості посушливих періодів - до 50 діб.

За відношенням до родючості грунту у насадженні переважають мегатрофи - 71,74 \% від загальної кількості дерев у насадженні, серед них найчисленніший вид - A. hippocastanum, кількість примірників якого становить 35,20 \% від кількості дерев групи мегатрофів. Група мезотрофів становить лише 2,02 \% від загальної кількості дерев і нечисельна за видовим складом. Представленість оліготрофів становить 26,20 \% від загальної кількості дерев парку, кількісно переважає B. pendula.

За даними проведеного аналізу грунту встановлено, що він відновиться до чорнозему звичайного важкосуглинистого, середньогумусного, характеризується забезпеченістю поживними елементами (азот, фосфор, калій) вище від середнього, реакція грунтового розчину нейтральна (табл. 7). Це свідчить про те, що в таких умовах добре будуть зростати представники всіх груп, і отже, асортимент деревних рослин за відношенням до багатства грунту в парку підібрано досить правильно [6].

Табл. 7. Показники аналізу грунту парку відпочинку смт Магдалинівка

\begin{tabular}{|c|c|c|c|c|c|}
\hline Горизонт, & \multirow{2}{*}{$\begin{array}{c}\text { смН } \\
\text { см }\end{array}$} & Гумус, & \multicolumn{3}{|c|}{ Вміст мг/100 г грунту } \\
\cline { 4 - 6 } & & $\%$ & $\mathrm{~N}$, & $\mathrm{P}_{2} \mathrm{O}_{2}$, & $\mathrm{K}_{2} \mathrm{O}$, \\
\hline $0-10$ & 6,9 & 5,1 & 2,5 & 13,1 & 15,0 \\
\hline $20-25$ & 7,0 & 5,3 & 2,7 & 13,5 & 15,2 \\
\hline
\end{tabular}

Результати проведеної естетичного оцінювання [13] наведено в табл. 8. За результатами визначення 14-ти показників, які надані в таксаційно-фітоценотичній шкалі, загальна оцінка становить 31 бал. 


\begin{tabular}{|l|c|c|}
\hline \multicolumn{1}{|c|}{1} & 2 \\
\hline Захаращеність ділянки & низька \\
\hline Ознаки грунтової ерозї & відсутні \\
\hline Ознаки ущільнення грунту & ледь помітні & 3 \\
\hline Ознаки ентомо-, фіто- та інших захворювань & помітні & 3 \\
\hline
\end{tabular}

Згідно з емоційною шкалою естетичного оцінювання фітоценозу парку, найбільшою кількістю балів (3 бали 3 оцінкою "подобається") було оцінено такі структурно-вікові показники: ярусність, зімкненість намету, та просторові показники - змішання порід, зручність пересування, розчленованість деревостану, колорит, освітленість (табл. 9).

Табл. 9. Емоційна шкала естетичного оцінювання фітоценозу парку відпочинку [13]

\begin{tabular}{|c|c|c|c|}
\hline Показник & $\begin{array}{c}\text { Подо- } \\
\text { бається } \\
\text { (3) }\end{array}$ & $\begin{array}{l}\text { Байду- } \\
\text { же (2) }\end{array}$ & $\begin{array}{c}\text { Не подо- } \\
\text { бається } \\
\text { (1) }\end{array}$ \\
\hline Фітоценоз загалом (попередня) & & 2 & \\
\hline $\begin{array}{l}\text { Структурно-вікові показники: } \\
\text { - продуктивність; } \\
\text { - ярусність; } \\
\text { - підріст; } \\
\text { - підлісок; } \\
\text { - трав'яний покрив; } \\
\text { - зімкнутість намету; } \\
\text { - змішання порід; } \\
\text { - вік }\end{array}$ & $\begin{array}{l}3 \\
3 \\
3\end{array}$ & 2 & $\begin{array}{l}1 \\
1 \\
1\end{array}$ \\
\hline $\begin{array}{l}\text { Просторові показники: } \\
\text { - глибина перспективи; } \\
\text { - зручність пересування; } \\
\text { - розчленованість деревостану } \\
\text { (групова, рівномірна, рядова); } \\
\text { - колорит (яскравий, контрастний } \\
\text { або спокійний); } \\
\text { - фактура дерева (груба, тонка); } \\
\text { - освітленість; } \\
\text { - модуляція виду (спричиняє по- } \\
\text { чуття неочікуваності) }\end{array}$ & $\begin{array}{l}3 \\
3 \\
3 \\
3\end{array}$ & $\begin{array}{l}2 \\
2 \\
2\end{array}$ & \\
\hline
\end{tabular}

Загалом здійснення естетичного оцінювання насадження за шкалою (табл. 10), яка містить дві шкали таксаційно-фітоценотичну (див. табл. 8) та емоційну (див. табл. 9), парк відпочинку віднесено до II класу естетичної цінності [11]. Оцінку 2 бали (або байдуже) отримали: фітоценоз загалом, продуктивність, глибина перспективи, фактура дерева, модуляція виду. Такі показники, як ярусність, підлісок та підріст, було занесено в таблицю з оцінкою один.

Табл. 10. Загальні результати естетичного оцінювання

\begin{tabular}{|l|c|}
\hline \multicolumn{1}{|c|}{ Назва } & Бал \\
\hline Походження & природне та штучне \\
\hline Бонітет & 2 \\
\hline Вологість грунту & 2 \\
\hline Рельєф & 3 \\
\hline Ярусність & 1 \\
\hline Підріст & 1 \\
\hline Підлісок & 2 \\
\hline Видовий склад трав'яного покриву & 2 \\
\hline Густота трав'яного покриву & 2 \\
\hline Господарська цінність деревостану & 2 \\
\hline Вік деревостану & 3 \\
\hline Зімкнутість намету & 3 \\
\hline Захаращеність ділянки & 3 \\
\hline Ознаки грунтової ерозії & 2 \\
\hline Ознаки ущільнення грунту & 1 \\
\hline Ознаки ентомо- та фітозахворювань & 32 \\
\hline Всього балів & 2,13 \\
\hline Середній бал & II \\
\hline Клас естетичної цінності & \\
\hline
\end{tabular}

Науковий вісник НЛТУ України, 2020, т. 30, № 1
У парку зростає багато деревних порід, які характеризуються високими показниками виділення летких речовин - фітонцидів. До складу яскраво виражених фітонцидних дерев та чагарників, що зростають на території парку смт Магдалинівка, належать $A$. platanoides, B. pendula [16], Syringa vulgaris, середні фітонцидні властивості мають $T$. cordata, A. hippocastanum та $S$. aucuparia $[13,24]$.

\section{Висновки:}

1. Дендрофлора парку відпочинку смт Магдалинівка представлена 19-ма видами, які належать до 15 родин. Загальна кількість дерев становить 347 прим., 3 яких 43,51 \% належать до гарноквітучих. Індекс видового багатства дорівнює 7,08, що менше, ніж у низці парків Дніпропетровської обл. Панівними породами є $A$. hippocastanum, U. scabra та B. pendula. Чисельність інтродукованих рослин становить $46,68 \%$.

2. Близько чверті дерев у насадженні парку мають висоту від 8,1 до 10 м - 23,3 \% від загальної кількості дерев. Дещо меншу, але вагому кількість мають групи зі значеннями 10,1-12,0 та 12,1-14,0 м - 19,9 та 15,0\%, відповідно. У насадженнях переважають дерева 3 діаметром від 22,1 до $26,0 \mathrm{~cm}-16,1 \%$, серед них багато A. hippocastanum, B. pendula та T. cordata. Найбільший діаметр (108 см) має 1 прим. P. alba.

3. Розподіл дерев за життєвим станом свідчить, що кількісно переважають особини, віднесені до 1-го класу життєвості (здорові), набагато менше - до інших класів. Індекс стану деревостану становить 80,14, що характеризує його як здоровий, хоча ця цифра знаходиться на нижній межі оцінки цієї категорії. Загалом асортимент деревних рослин парку смт Магдалинівка за відношенням до екологічних чинників підібрано правильно.

4. За комплексною шкалою, яка містить в собі дві шкали - емоційну та таксаційно-фітоценотичну, парк відпочинку віднесено до II класу естетичної цінності.

\section{References}

1. Alekseev, V. A. (1989). Diagnostics of the vital state of trees and tree stand. Russian Journal of Forest Science, 4, 51-57. [In Russian].

2. Arynushkyna, E. V. (1970). Manual of chemical soil analysis. Moscow: Publishing House of Moscow university, 487 p. [In Russian].

3. Belgard, A. L. (1971). Forest steppe. Moscow: Lesnaja promyshlennost, 336 r. [In Russian].

4. Bessonova, V. P., \& Ivanchenko, O. E. (2013). Analysis of the species composition and condition of the woody vegetation of the park named after B. Khmelnytskyi in the city of Dnipropetrovsk. (Ser. Forestry and Decorative Gardening). Scientific Herald of NULES of Ukraine, 187(1), 11-15. [In Ukrainian].

5. Bessonova, V. P., \& Ivanchenko, O. E. (2015). Analysis of dendroflora plantations Molodejney park of Dnipropetrovsk. (Ser. Biology \& Ecology). Scientific journal of Poltava V. G. Korolenko National Pedagogical University, 1(1), 20-32. [In Ukrainian].

6. Bessonova, V. P., Ponomarjova, E. A., \& Ivanchenko, O. E. (2014). Dendroflora of Dnipropetrovsk Yu. Gagarin Park. The Scientific Bulletin of UNFU, 24(1), 63-69. [In Ukrainian].

7. Bidolah, D. I., Grynjuk, Ju. G., \& Shljahta, Ja. M. (2012). Features of the reconstruction of leisure parks of small cities in the West of Ukraine on the example of Zborovskyi city park. (Ser. Forestry and Decorative Gardening). Scientific Herald of NULES of Ukraine, 171(1), 28-33. [In Ukrainian].

Scientific Bulletin of UNFU, 2020, vol. 30, no 1 
8. Grycajenko, Je. M., Grycajenko, A. O., \& Karpenko, V. P. (2003). Methods of biological and agrochemical studies of plants and soils. Kyiv: ZAT "NICHLAVA", 320 p. [In Ukrainian].

9. Hrytsai, N. B. (2018). The taxonomic structure of dendroflora of the Youth park in Rivne city. Biology and Ecology, 4(1), 27-33. https://doi.org/10.5281/zenodo.1318164

10. Ilchuk, N. I., \& Martin, O. D. (2017). Reconstruction of the central park of culture and rest in the village Lyubeshov of the Volyn region. Modern technologies and calculation methods in construction, 7, 89-93. [In Ukrainian].

11. Ivanchenko, O. E. (2017). Contemporary condition of dendroflora of the culture and recreation park in Vilnohirsk, Dnipropetrovsk region. Problems of bioindications and ecology, 22(2), 39-61. [In Ukrainian].

12. Kowalski, V., \& Vityuk, I. (2016). Factors influence on formation and accommodation garden and parking objects. Modern technology, materials and design in construction, 2, 69-73. [In Russian].

13. Kucherjavyj, V. P. (2008). Landscaping of populated areas. Lviv: Svit, 456 p. [In Ukrainian].

14. Lazarenko, P. I. (1995). Bio-ecological principles of the territory division into agricultural districts (Dniepropetrovsk region example). Kyiv: Porogy, 476 p. [In Ukrainian].

15. Masalskiy, V. P., \& Kuznetsov, S. I. (2018). The impact of park planting on the urbanized environment. Scientific Bulletin of UNFU, 28(7), 49-52. https://doi.org/10.15421/40280710

16. Myshukova, Y. A., Lebedev, P. A., \& Krjukovskyj, A. S. (2017). The principles of selection of the assortment of plants when creating recreation gardens on the territory of medical institutions. Actual problems of the humanities and natural sciences, 10(2), 10-14. [In Russian].

17. Pogorelov, A. D., \& Lipilin, D. A. (2017). Green spaces of Krasnodar city. Evaluation and multi-year changes. PNRPU Bulletin.
Urban development, 31, 192-205. https://doi.org/10.15593/2409$\underline{5125 / 2017.03 .15}$

18. Pogrebnjak, P. S. (1963). General forestry. Moscow: Selhozgiz, 250 r. [In Russian].

19. Pototska, S. A. (2012). Comparative analysis dendroflora green spaces cities of chernihiv. (Ser. Biology). Scientific Bulletin of Uzhgorod University, 33, 64-70. [In Ukrainian].

20. Prohorenko, O. T., \& Adamenko, T. I. (Eds). (2011). Agroclimatic reference book in the Dnipropetrovsk region. Dnipropetrovsk: Poligraf-Media, 231 p. [In Ukrainian].

21. Reshetyuk, O. V. (2017). The prospect of using natural reserve fund parks in Bukovyna for its biodiversity enrichment. Scientific Bulletin of UNFU, 27(10), 42-50. https://doi.org/10.15421/40271006

22. Rogovskyi, C. V. (2019). Current problems of greenery creation and maintenance in Ukrainian localities. Scientific Bulletin of $U N$ FU, 29(1), 9-15. https://doi.org/10.15421/40290101

23. Sholok, I. V. (2014). Comparative analysis of large cities greening in Ukraine and Europe. (Ser. Ecology). Journal of V. N. Karazin Kharkiv National University, 1140(11), 42-49. [In Ukrainian].

24. Starovojtova, T. V., Lahno, E. S., \& Jaroshenko, V. A. (1964). Phytoncide activity of plants in natural conditions. Phytoncides in the natural economy, (pp. 77-78). Kyiv: Scientific thought. [In Russian].

25. Supluva, N. O. (2014). Inventory Research of Parks Monuments of Landscape Art in Vinnitsa Region. Proceedings of the National Museum of Natural History, 12, 116-122. [In Ukrainian].

26. Terlyga, N. S., Danilchuk, A. V., Yukhimenko, Yu. S., Fedorovsky, V. D., \& Danilchuk, N. M. (2015). Kryvyi Rig parks and squares cultivated dendroflora: historical aspects of formation and current state. (Ser. Biology). The Bulletin of Kharkiv National Agrarian University, 2(35), 93-101. [In Ukrainian].

27. Zajachuk, V. Ja. (2008). Dendrology. Lviv: Apriori, 665 p. [In Ukrainian].

V. P. Bessonova, O. E. Ivanchenko

Dnipro State Agrarian and Economic University, Dnipro, Ukraine

\section{SPECIES RICHNESS OF DENDROFLORA AND AESTHETIC ASSESSMENT OF PHYTOCENOSES OF THE PARK OF MAHDALYNIVKA TOWN}

The dendroflora of the park in Mahdalynivka town is represented by 347 specimens, which belong to 19 species and 15 families. Among the plants, Aesculus hippocastanum, Ulmus scabra, Betula pendula are dominating. Families are predominantly represented by 1-2 species, with the exception of Rosaceae. The families Hippocastanaceae, Ulmaceae and Betulaceae are represented in great numbers of instances in the planting. Indigenous species account for $53.32 \%$. The largest percentage of the total number of introducers are representatives of southern and southeastern Europe. The predominant number of trees in the plantation has a height ranging from 8.1 to $10.0 \mathrm{~m}(23.3 \%$ of all plants). Relative to the diameter of the stem, trees dominate with values of this indicator from 22.1 to $26.0 \mathrm{~cm}(16.1 \%)$, numerous are groups of plants with diameters of $26.1-30 ; 34.1-38$ and from $18.1-22 \mathrm{~cm}$. The diameter of one of the oldest trees in the park (Populus alba) is $108 \mathrm{~cm}$. In terms of vitality, slightly more than half of the woody plants belong to the "healthy" category, among them there are many Betula pendula, Juglans regia, Ulmus scabra, Tilia cordata. There are 110 weakened trees belong them, the very weakened -43 , and among dying trees, there are only 6 trees. In the plans, there are cases of trunk faunality, frost cracks, drying out of branches, hollows, warts (burls). The forest stand state index for the park is 80.14 , which characterizes it as healthy. Regarding environmental requirements, the range of the park only partially corresponds to the conditions of moistening the territory, but almost completely - to the fertility of the soil. According to the taxation-phytocenotic scale, the overall aesthetic assessment of the phytocenosis of the park is 31 points, according to the aesthetic - to the II class of aesthetic value. The following indicators were rated with the highest number of points: tier, crown density, as well as spatial - mixing of species, ease of movement, color, and illumination. Trees with expressed phytoncide activity grow in the park, namely Acer platanoides, Betula pendula, Syringa vulgaris, as well as Tilia cordata, Aesculus hippocastanum and Sorbus aucuparia.

Keywords: rural park; tree plantations; species diversity; taxation characteristics; vitality condition; taxation-phytocenotic and emotional scales. 